\title{
Trait-based algal community assembly associated with Pectinatella magnifica (Bryozoa, Phylactolaemata)
}

\author{
Hyo Gyeom Kim¹, Hak Young Lee ${ }^{2}$ and Gea-Jae Joo ${ }^{1, *}$ \\ ${ }^{1}$ Department of Biological Sciences, Pusan National University, Busan 46241, Korea \\ ${ }^{2}$ Department of Biological Sciences, Chonnam National University, Gwangju 61186, Korea
}

\begin{abstract}
Habitat-forming species increase spatial complexity and alter local environmental conditions, often facilitating the assembly of plants and animals. We conducted a trait-based approach to algal assemblages associated with the freshwater bryozoan, Pectinatella magnifica. Association with algae leads to the inner bodies of the bryozoans being colored green; this is frequently observed in the large rivers of South Korea. We collected the green-colored gelatinous matrices and phytoplankton from waterbodies of the two main rivers in South Korea. Algal assemblages within the colonies and in the waterbodies were compared using the three diversity indices (richness, diversity, and dominance), and the composition of functional groups (FGs) and morphologically based functional groups (MBFGs) between the colonies within and outside of P. magnifica colonies. The most dominant and common species within the colonies were Oscillatoria kawamurae and Pseudanabaena catenata, both of which were assigned to the same FG (codon S1). Of the algal assemblages within the colonies, the dominance was higher, while the richness and diversity were lower, than those in the waterbodies. There was variation in the compositions of FGs and MBFGs in the waterbodies outside the colonies. Total nitrogen and orthophosphate led to dominance, and were significant factors for the variation in FGs in the waterbodies, whereas there were no such significant factors within the colonies. This trait-based approach to the community structure of associated algae provides the status and habitat gradient of these communities, which are stable, isolated, and consistent with the overgrowth of shade-adapted tychoplanktonic cyanobacteria.
\end{abstract}

Key Words: algal communities; associated algae; biodiversity; bryozoan; functional classification; morphologically based functional classification

Abbreviations: ANOSIM, analysis of similarities; BOD, biological oxygen demand; Chl $a$, chlorophyll $a$; FG, functional group; MBFG, morphologically based functional group; $\mathrm{NH}$, ammonium; NMDS, non-metric multidimensional scaling; PERMANOVA, permutational multivariate analysis of variance; PO, orthophosphate; RDA, redundancy analysis; SIMPER, similarity percentage analyses; TN, total nitrogen; TP, total phosphorus

\section{INTRODUCTION}

Habitat-forming species increase spatial complexity and alter local environmental conditions, often facilitating the assemblage of specific fauna and flora (Stimson 1985, Bertness et al. 1999). In an environmental regime, the diversity and structure of a community can critically depend on positive associations with a single dominant species (Lilley and Schiel 2006). However, the stability of habitats generated by different organisms fluctuate and
(9) $\$$ This is an Open Access article distributed under the terms of the Creative Commons Attribution Non-Commercial License (http://creativecommons.org/licenses/by-nc/3.0/) which permits unrestricted non-commercial use, distribution, and reproduction in any medium, provided the original work is properly cited.
Received December 14, 2018, Accepted May 3, 2019

* Corresponding Author

E-mail: gjjoo@pusan.ac.kr

Tel: +82-51-510-2258, Fax: +82-51-581-2962 
are usually unpredictable, as the biological processes between organisms can vary from competing for light or resources to mutualism (Wood et al. 2012). One promising method of predicting stability is to evaluate these environmental regimes based on the characteristics of established communities (Lavorel et al. 1997, McGill et al. 2006). Aggregated estimates of algal communities (e.g., total biomass and diversity indices) can be used to describe the overall community response to various environmental conditions (Vollenweider 1976, Magurran 1988). However, in terms of phytoplankton autecology, each species has their own functional traits, which consist of physiological, morphological, and phenological features. Functional non-taxonomical classifications of organisms could simplify the complexity of ecosystems and be representative of the trophic state or habitat preference (Litchman et al. 2010, Kruk et al. 2011). This traitbased classification of phytoplankton, based on similar biological properties, can help to elucidate the structure and delineate the trophic state or habitat characteristics of these communities (Salmaso et al. 2015). Habitat templates have been created for phytoplankton of different species by combining the characteristics and environmental gradients. Reynolds et al. (2002) and Padisák et al. (2009) proposed placing algal species with similar adaptation abilities to environmental constraints into functional groups (FGs). In addition, based on the correlation between the morphological and functional features, defined morphologically based functional groups (MBFGs) are well predicted based on various environmental conditions (Kruk et al. 2010, 2011).

Freshwater bryozoans belong to the phylum Bryozoa, consisting of aquatic sessile invertebrates. These species secrete gelatinous material, which may act as microhabitats for other organisms (Bushnell and Rao 1979). Pectinatella magnifica (Leidy, 1851), a freshwater bryozoan, is usually observed in stagnant parts of rivers or lakes. This species was introduced to South Korea in the 1970s and 1980s, and abruptly showed a massive population spread through the country's main rivers in 2014 (Seo 1998, Jo et al. 2014). When found in rivers or lakes, they generally form a green or blue-green colored matrix due to the algae that grow within the colony. The algal assemblages associated with $P$. magnifica are dominated by bluegreen algae with a high cell density; the bryozoan matrix is a nutrient-rich environment (Joo et al. 1992, Šetlíková et al. 2013). However, these biological relationships have not received much attention from ecologists and physiologists. Furthermore, the quantitative measurement of abundance and the reasons why certain species are found under these specific environmental conditions have not been elucidated.

The aims of this research are as follows: (1) to quantitatively analyze associated algal communities and (2) to determine the habitat characteristics of the P. magnifica matrix based on the algal community assembly traits by comparing them to those in surrounding water columns. We applied three widely used ecological diversity indices and two novel functional classification schemes to phytoplankton to analyze the algal community traits both within the colonies and in the studied waterbodies.

\section{MATERIALS AND METHODS}

\section{Study site and sampling}

We monitored P. magnifica colonies and associated algae in two of the main river channels (Geum River and Nakdong River) of South Korea. The Geum River is located in the central-western part (length, $397 \mathrm{~km}$; basin width, $9,885 \mathrm{~km}^{2}$ ), and the Nakdong River in the southeastern part of the country (length, $514 \mathrm{~km}$; basin width, 23,860 $\mathrm{km}^{2}$ ). The five sampling sites are shown in Fig. 1A; there are two sites from the Geum River and three sites from the Nakdong River. Three sites are located upstream of weirs where the river flow is stagnant, allowing P. magnifica to grow at a stable rate. The remaining two sites, Banbyeon and Miryang, are tributaries of the Nakdong River, and it has been reported that bryozoans occur in high densities in those areas (Jo et al. 2014).

Field surveys were conducted a total of six times from June to August in 2015, as P. magnifica reached their maximum growth in the summer. The colonies that showed green internal matrices were detached from the substrate and collected in $50 \mathrm{~mL}$ conical tubes (Fig. 1B). Samples for analyzing phytoplankton in the waterbodies were collected from the surface water $(0.5 \mathrm{~m})$ by using a water sampler $(8 \mathrm{~L})$ at each of the sampling sites simultaneously with the colony matrix and transferred to $100 \mathrm{~mL}$ plastic bottles. Both samples for quantitative algal composition analyses were fixed with Lugol's solution (final concentration: $\sim 3 \%$ ) and analyzed within a few days.

The identification and enumeration of algal assemblages were performed according to LeGresley and McDermott (2010). The abundances of the algal assemblages were determined by counting the independent cells in the Sedgwick Rafter chamber after full sedimentation using a microscope ( $\times 200$ and $\times 400$ magnification; Axioskop 40; ZEISS, Jena, Germany). Because the freshwater bryo- 

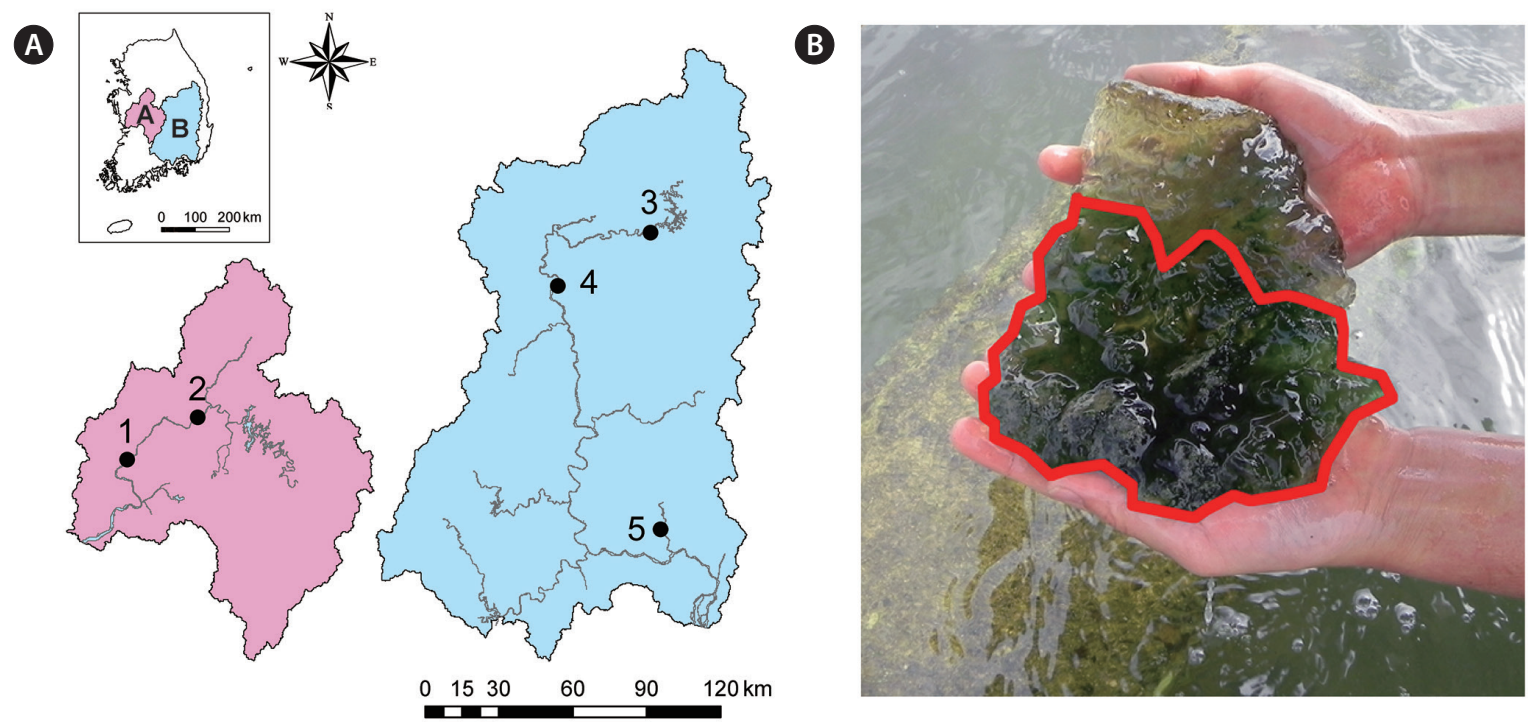

Fig. 1. (A) Map of the Geum River, Nakdong River basin, and study sites (left side, Geum River; right side, Nakdong River; 1, Sejong weir; 2 , Paekche weir; 3, Banbyeoncheon; 4, Nakdan weir; 5, Miryang stream). (B) Image of Pectinatella magnifica. Convex line shows the association between the algae and bryozoans.

zoan body consists of gelatinous material, which makes sedimentation difficult, cell counts were performed with a microscope with multiple focal points. The classification rule was based on Akiyama (1977) and Yamagishi and Akiyama (1984). Algae were taxonomically identified to the species level when possible, and their biovolumes were calculated from measurements of linear dimensions of cells measured under the microscope using the appropriate formulae and geometric shapes (Hillebrand et al. 1999). These biovolumes were converted into biomass $\left(\mathrm{mg} \mathrm{L}^{-1}\right)$ on the basis of a phytoplankton cell density of $1 \mathrm{mg} \mathrm{mm}^{-3}$.

Physicochemical parameters were simultaneously measured at the study sites. Water temperature and dissolved oxygen were measured using a YSI 58 dissolved oxygen probe, and the conductivity was measured using a YSI 30 salinity meter (YSI, Yellow Springs, OH, USA). The $\mathrm{pH}$ and turbidity were measured using an Orion 407A Ionanalyzer (Thermo Fisher Scientific, Chelmsford, MA, USA) and Micro100 turbidity meter (HF Scientific, Fort Myers, FL, USA), respectively. The alkalinity was determined by titrating $\mathrm{H}_{2} \mathrm{SO}_{4}$ against a water sample. The flow velocity was measured using Flowatch (Ecomac, Anyang, Korea), and the discharge data from the sampling days were obtained from the Korean National Water Resource Management Information System. Other water quality data, which were monitored by the Nakdong River Environmental Research Center, were collected, including biological oxygen demand (BOD), chemical oxygen de- mand, total nitrogen (TN), total phosphorus (TP), total organic carbon, chlorophyll $a$ (Chla), dissolved inorganic nitrogen, ammonium $(\mathrm{NH})$, nitrate, and orthophosphate (PO).

\section{Ecological diversity and functional properties}

To evaluate the ecological stability, we used three indices of richness, diversity, and dominance. The species richness index (Margalef's index) and indices based on the proportional abundance of species (Shannon index and Simpson's dominance index) (Magurran 1988) were calculated for each sample in terms of the phytoplankton cell density. Each index was subjected to Student's t-test to determine any differences in algal communities between two environmental regimes, within the colonies and in the waterbodies (Zar 1999).

To explain algal community structures in terms of the functional properties of species, we applied two schemes, functional classification and morphologically based functional classification, to each algae species. We allocated taxa to FGs based on Reynolds et al. (2002) and Padisák et al. (2009), and morpho-functional groups (MBFGs) based on Kruk et al. (2010). Because of the difficulty in identifying species of centric diatoms, the organisms were allocated to FGs according to their critical diameter as $10 \mu \mathrm{m}\left(10^{3} \mu \mathrm{m}^{3}\right.$ in volume). Groups contributing more than $1 \%$ of total phytoplankton biomass on a natural-log scale at least once during sampling period 
were referred as "prevailing groups." Statistical analyses were performed using the software IBM SPSS ver. 23 (IBM Corp., Armonk, NY, USA).

\section{Assessing differences among and within envi- ronmental regimes}

To assess the spatial heterogeneity in FG and MBFG composition, we performed non-metric multidimensional scaling (NMDS) with two environmental regimes and five sites. We natural-log transformed each biomass data entry. For NMDS, we used the Bray-Curtis coefficient to ordinate the algal species biomass and performed a Monte Carlo randomization test $(\mathrm{n}=999)$ to determine the significance of the final stress values (a measure of goodness of fit). To evaluate significant differences between the groupings by environmental regime and site, we conducted 2 resemblance-based permutation tests of taxon similarity: pair-wise analysis of similarities (ANOSIM) and permutational multivariate analysis of variance (PERMANOVA). While the robustness of pair-wise ANOSIM is advantageous, it does not test for interactions on whether factor effects on assemblage differences are independent or are the result of a combination of both factors. PERMANOVA can deconstruct the effects into main effects and interactions, and therefore, complements ANOSIM. These permutational analyses were performed using 999 permutations. Where differences were significant, FG and MBFG that were responsible for driving changes in community composition were identified using similarity percentage analyses (SIMPER), using 999 permutations. Groups that contributed more to similarity, when the average similarity values / standard deviation $>1$, were considered useful to discriminate habitats (Ruhí et al. 2011). All the multivariate analyses and visualization were performed using the 'vegan' and 'ggplot2' packages within RStudio (ver. 1.0.136; RStudio, Boston, MA, USA).

\section{Relationships between the environmental vari- ables and phytoplankton functional groups}

If both analyses (t-test and NMDS) of the two comparative studies showed significant differences in FG and MBFG composition independently of sampling site, a redundancy analysis (RDA) was used to determine the relationship between the environmental factors and the group composition. We transformed the environmental and species data, and the significance of the environmental variables in explaining the variance in the group composition from the RDA was tested using Monte Carlo simulations with stepwise selection. Ordinations were performed using the 'vegan' package within RStudio (ver. 1.0.136; RStudio).

\section{RESULTS}

\section{Physical conditions}

Table 1 summarizes the values of the main physical and chemical parameters of Geum River and Nakdong River during the study. Because the study period was during summer (from June to August), the water temperature was high $\left(27.2 \pm 1.8^{\circ} \mathrm{C}\right)$. The river depth was the highest at site 4 of Nakdan weir, the discharge was the highest at site 1 of Bakje weir, and all sites had a low flow velocity $\left(<5.0 \mathrm{~m} \mathrm{~s}^{-1}\right)$. Two rivers had experienced eutrophication; the average TP and PO were $38.0 \mu \mathrm{g} \mathrm{L} \mathrm{L}^{-1}$ and $10.1 \mu \mathrm{g} \mathrm{L} \mathrm{L}^{-1}$, respectively. The mean Chl $a$ value of all measurements was $28.9 \mathrm{mg} \mathrm{L}^{-1}$, and the value of the Geum River was higher than the one of the Nakdong River. A total of 13 colonies were collected from five sites (sites 1 and 5: 2 each; sites 2-4: 3 each). Colonies of various sizes were collected, with a size range of $330-4,055 \mathrm{~cm}^{3}$ and a mean volume of 1,293 $\pm 329 \mathrm{~cm}^{3}$.

\section{Community difference between inner and outer Bryozoan}

Biomass values and the number of species were significantly different between within and outside of $P$. magnifica $(\mathrm{t}=-5.995, \mathrm{p}=0.000 ; \mathrm{t}=1.803, \mathrm{p}=0.096)$ (Fig. $2 \mathrm{~A}$ \& B). Fewer species (7.1 \pm 3.1$)$ lived within the bryozoans at higher densities $\left(81.2 \pm 41.7 \mathrm{mg} \mathrm{L}^{-1}\right)$ than in the waterbodies $\left(22.4 \pm 9.7\right.$ ind. $\left.\mathrm{mL}^{-1}, 5.9 \pm 3.1 \mathrm{mg} \mathrm{L}^{-1}\right)$. The algal assemblages reached a maximum biomass of $423.7 \mathrm{mg} \mathrm{L}^{-1}$ in the bryozoan, which was much lower than that in the waterbodies $\left(7.6 \mathrm{mg} \mathrm{L}^{-1}\right)$. The common dominant algal species in terms of their biomass within P. magnifica was Pseudanabaena catenata Lauterborn $1915\left(1.9 \mathrm{mg} \mathrm{L}^{-1}\right)$, and the most abundant species was Oscillatoria kawamurae Negoro 1943 (76.3 $\mathrm{mg} \mathrm{L}^{-1}$ ). The other taxonomic groups, such as Bacillariophyceae and Chlorophyceae were rarely observed in the algal assemblage, showing a relative abundance of below $0.5 \mathrm{mg} \mathrm{L}^{-1}$. By contrast, diatoms (4.2 $\left.\mathrm{mg} \mathrm{L}^{-1}\right)$ and green algae (1.1 $\left.\mathrm{mg} \mathrm{L}^{-1}\right)$ contributed more to the phytoplankton biomass in the waterbodies than did cyanobacteria $\left(0.6 \mathrm{mg} \mathrm{L}^{-1}\right)$. Aulacoseira of cylindrical diatoms $\left(0.9 \mathrm{mg} \mathrm{L}^{-1}\right)$ were the common dominant genus, 

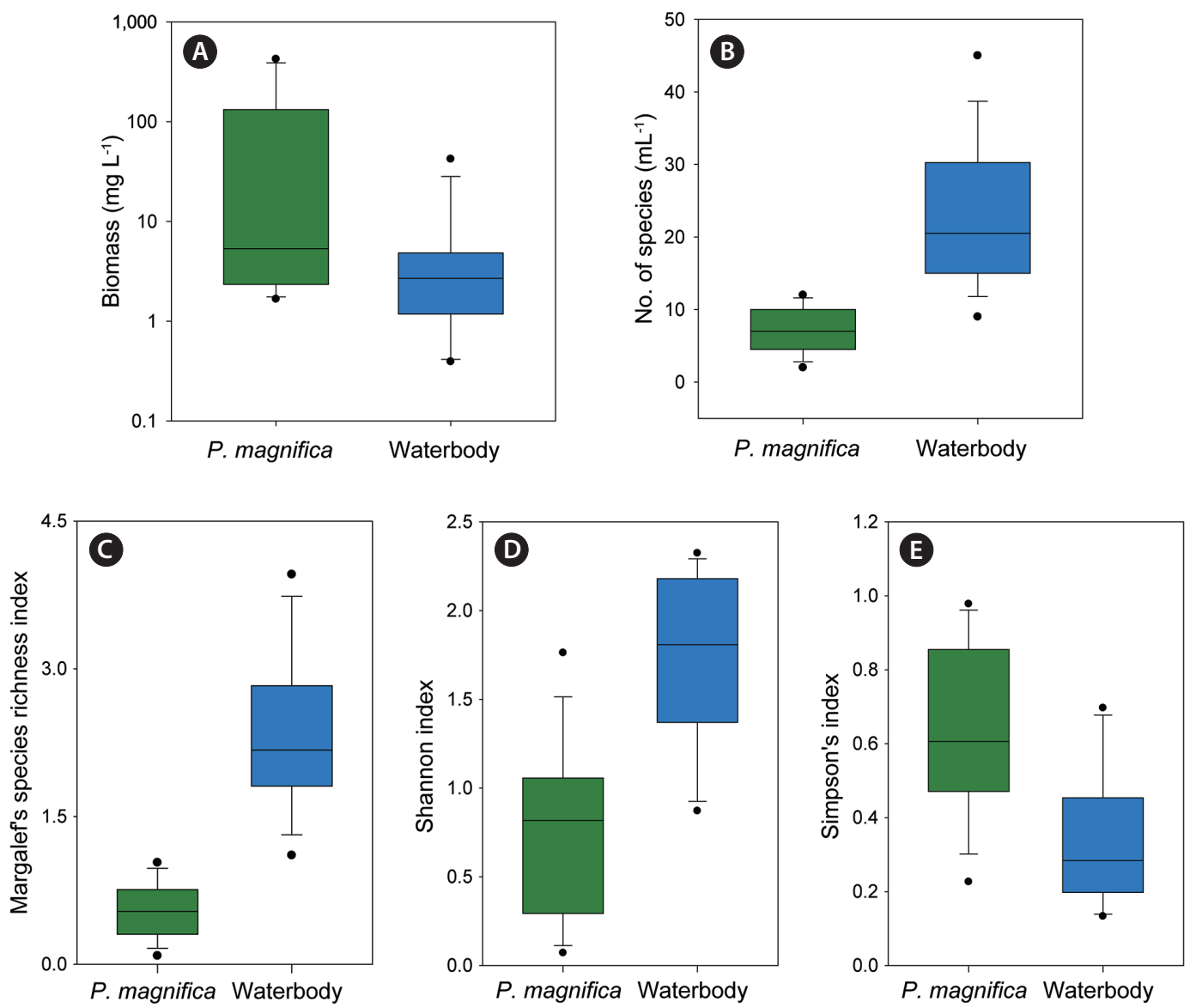

Fig. 2. Comparison of cell densities of Pectinatella magnifica on a logarithmic scale (A), the number of species (B), and diversity indices of richness (C), diversity (D), and dominance (E) between two environmental regimes.

Table 1. Mean and range values of the main limnological parameters of the sampling sites in the Geum River and Nakdong River in the summer of 2015

\begin{tabular}{|c|c|c|c|c|c|}
\hline \multirow{2}{*}{ Water quality parameter } & \multicolumn{2}{|c|}{ Geum River } & \multicolumn{3}{|c|}{ Nakdong River } \\
\hline & Sejong & Bakje & Banbyeon & Nakdan & Milryang \\
\hline Water temperature $\left({ }^{\circ} \mathrm{C}\right)$ & $26.3(22.9-29.1)$ & $28.0(25.8-32.2)$ & $25.3(22.2-28.1)$ & $27.4(24.8-30.8)$ & $25.4(23.9-28.2)$ \\
\hline Dissolved oxygen $\left(\mathrm{mg} \mathrm{L}^{-1}\right)$ & $13.5(7.5-17.8)$ & $10.3(9.2-11.5)$ & $9.3(8.3-10.2)$ & $10.8(7.9-12.2)$ & $8.8(7.5-9.9)$ \\
\hline $\mathrm{pH}$ & $8.7(7.2-9.2)$ & $8.6(7.7-9.3)$ & $8.1(7.6-8.7)$ & $8.7(7.9-9.4)$ & $8.3(7.9-9.0)$ \\
\hline Conductivity $\left(\mu \mathrm{sm}^{-1}\right)$ & $373(280-448)$ & $341(245-402)$ & $208(190-242)$ & $258(227-295)$ & $180(169-200)$ \\
\hline Turbidity (NTU) & $11.1(7.4-16.0)$ & $11.1(6.3-13.7)$ & $6.1(2.6-9.9)$ & $4.4(3.2-6.3)$ & $5.2(1.8-6.9)$ \\
\hline Alkalinity $\left(\mathrm{mg} \mathrm{L}^{-1}\right)$ & $43(30-62)$ & $61(56-66)$ & $43(36-54)$ & $56(40-68)$ & $44(42-48)$ \\
\hline Depth $(\mathrm{cm})$ & $78.8(70.0-90.0)$ & $81.5(78.0-85.0)$ & $34.9(29.5-38.8)$ & $115.6(92.0-139.0)$ & $44.7(36.6-52.5)$ \\
\hline Flow velocity $\left(\mathrm{m} \mathrm{sec}^{-1}\right)$ & $1.4(0.0-5.0)$ & $0.4(0.0-2.0)$ & $3.4(1.1-5.3)$ & $0.4(0.0-2.0)$ & $2.9(0.0-7.5)$ \\
\hline Discharge $\left(\mathrm{m}^{3} \mathrm{sec}^{-1}\right)$ & $109.2(49.3-313.7)$ & $154.6(50.9-509.8)$ & $9.5(5.7-13.9)$ & $52.3(37.3-68.2)$ & $11.9(4.4-26.7)$ \\
\hline $\mathrm{BOD}\left(\mathrm{mg} \mathrm{L}^{-1}\right)$ & $2.9(1.6-4.1)$ & $2.4(2.1-2.6)$ & $1.1(0.9-1.4)$ & $2.2(1.5-2.8)$ & $1.7(1.4-1.8)$ \\
\hline $\mathrm{COD}\left(\mathrm{mg} \mathrm{L}^{-1}\right)$ & $7.6(5.9-8.6)$ & $6.9(6.0-7.3)$ & $4.2(3.4-5.0)$ & $5.4(5.2-5.6)$ & $3.9(3.8-4.2)$ \\
\hline $\mathrm{TN}\left(\mathrm{mg} \mathrm{L}^{-1}\right)$ & $2.6(2.0-2.9)$ & $2.0(1.5-2.8)$ & $1.7(1.3-2.3)$ & $1.6(1.0-2.0)$ & $1.7(1.1-2.5)$ \\
\hline $\mathrm{TP}\left(\mu g \mathrm{~L}^{-1}\right)$ & $83(60-125)$ & $64(45-86)$ & $18(12-28)$ & $32(18-45)$ & $34(19-56)$ \\
\hline $\mathrm{TOC}\left(\mathrm{mg} \mathrm{L}^{-1}\right)$ & $4.7(3.4-6.6)$ & $4.2(3.7-4.9)$ & $2.5(2.2-2.6)$ & $3.3(2.7-3.8)$ & $3(2-3.4)$ \\
\hline Chl $a\left(\mu \mathrm{L} \mathrm{L}^{-1}\right)$ & $80.2(16.5-133.7)$ & $37.6(24.7-52.9)$ & $4.3(3.0-7.0)$ & $12.9(7.3-16.8)$ & $13.2(6.0-27.3)$ \\
\hline $\mathrm{NH}\left(\mathrm{mg} \mathrm{L}^{-1}\right)$ & $0.1(0-0.1)$ & $0.2(0.1-0.4)$ & $0.1(0.0-0.2)$ & $0.1(0.0-0.1)$ & $0.0(0.0-0.1)$ \\
\hline $\mathrm{NO}\left(\mathrm{mg} \mathrm{L}^{-1}\right)$ & $1.8(1.6-2.0)$ & $1.3(1.0-1.5)$ & $1.2(1.0-1.5)$ & $1.0(0.6-1.3)$ & $1.1(0.6-1.5)$ \\
\hline $\mathrm{PO}\left(\mu \mathrm{g} \mathrm{L}^{-1}\right)$ & $19(4-62)$ & $23(12-52)$ & $6(2-9)$ & $5(0-11)$ & $14(5-24)$ \\
\hline
\end{tabular}

$\mathrm{BOD}$, biological oxygen demand; COD, chemical oxygen demand; TN, total nitrogen; TP, total phosphorus; TOC, total organic carbon; Chla, chlorophyll $a$; NH, ammonium; NO, nitrate; PO, orthophosphate. 

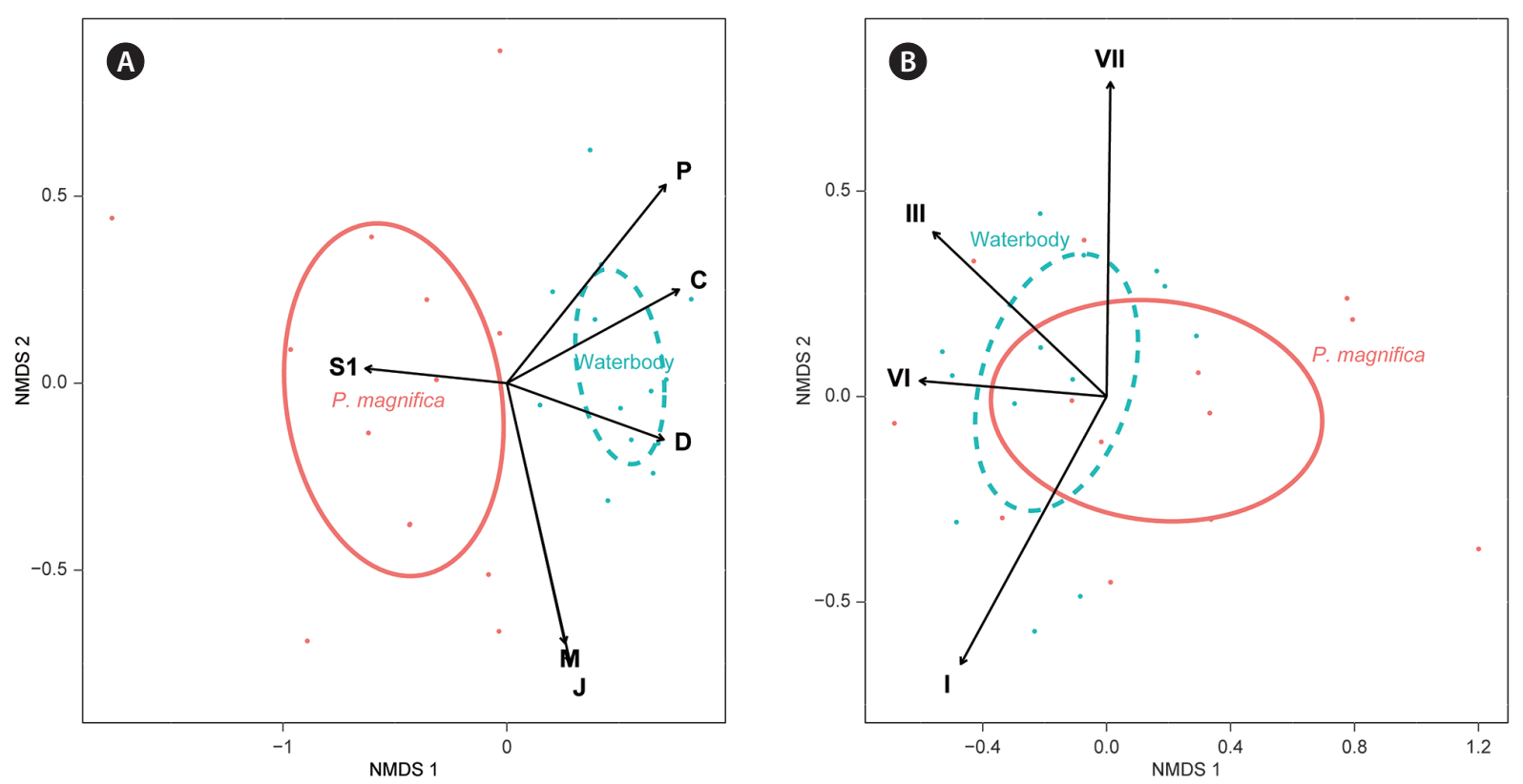

Fig. 3. Non-metric multidimensional scaling ordination of algal species (A) and functional group composition (B) by environmental regime. Vectors displayed are significant at $p<0.01$. The $95 \%$ confidence interval ellipses are displayed for within Pectinatella magnifica and in the waterbodies. NMDS, non-metric multidimensional scaling.

and Cyclotella of centric diatoms $\left(3.0 \mathrm{mg} \mathrm{L}^{-1}\right)$ showed the highest density in the surrounding water column.

All three indices of species richness, diversity, and dominance were significantly different on within and outside of $P$. magnifica (Fig. 2C-E). The index of richness within the colony (0.09-1.0) was lower than that outside the colony $(1.1-4.0 ; \mathrm{t}=-4.561, \mathrm{p}<0.01)$. The richness was the lowest within P. magnifica when only two algal species, Pseudanabaena catenata and Pseudanabaena sp., were observed. The diversity index within the bryozoan $(0.74 \pm 0.13)$ was lower than that outside $(1.73 \pm 0.12 ; \mathrm{t}=$ $-5.584, \mathrm{p}<0.01)$, and the dominance index within $(0.65 \pm$ $0.22)$ was higher than that outside $(0.33 \pm 0.04 ; \mathrm{t}=4.292$, $\mathrm{p}<0.01$ ), showing that the algal communities within the bryozoan matrix were less diverse than those in the surrounding waterbodies.

\section{Differences in functional groups and morpho- logically based on functional groups}

Altogether, 18 phytoplankton FGs and all seven MBFGs, comprising 101 species, were identified during the experimental period (Supplementary Table S1). There were nine prevailing FGs within P. magnifica (namely groups $\mathrm{B}, \mathrm{G}, \mathrm{H} 1, \mathrm{~J}, \mathrm{M}, \mathrm{MP}, \mathrm{N}, \mathrm{P}, \mathrm{S} 1$, and $\mathrm{W}_{\mathrm{S}}$ ) and 11 prevailing FGs outside the colonies (groups A, B, C, D, H1, J, M, MP, P, S1, and X1). The MBFG compositions were analyzed using all seven groups, because both prevailing groups in the two environmental regimes corresponded to whole groups. The dominant group was codon S1 in the P. magnifica matrix $\left(78.0 \pm 41.2 \mathrm{mg} \mathrm{L}^{-1}\right)$ and codon $\mathrm{B}$ in the waterbodies $\left(3.0 \pm 3.0 \mathrm{mg} \mathrm{L}^{-1}\right)$. Groups A, C, and D recognized only in waterbodies, and group $\mathrm{N}$ was encountered only within the colonies. Within the colonies, the dominant group of associated algae was group III (76.4 $\pm 41.3 \mathrm{mg} \mathrm{L}^{-1}$ ), which consisted of medium-sized organisms lacking special traits. In the waterbodies, group VI was the most abundant $\left(4.2 \pm 3.0 \mathrm{mg} \mathrm{L}^{-1}\right)$ with the contribution of $25.1 \%$ to total phytoplankton biomass on average, comprising non-flagellated organisms with a siliceous skeleton. All seven MBFGs were observed in both of environmental regimes (Table 2).

There were significant differences in FG composition between the two environmental regimes (Table 3). The variable-loading results showed that six of 19 FGs contributed significantly $(\mathrm{p}<0.01)$ to the ordination axis (Fig. $3 \mathrm{~A})$. The high percentage of group S1 organisms within P. magnifica was the primary feature of the functional difference, and group $\mathrm{C}$ was the most important in the FG of algal communities in the waterbodies. There was more similarity in FG composition within environmental regimes than between them $(\mathrm{R}=0.599, \mathrm{p}=0.001)$. The PERMANOVA results showed significant differences in community composition between environmental re- 
gimes (pseudo- $\mathrm{F}_{1,25}=16.206, \mathrm{p}=0.001$ ), independent of the sampling site (pseudo- $\mathrm{F}_{4,25}=1.168, \mathrm{p}=0.330$ ). Results of SIMPER analysis showed that the differences between within and outside the colonies could largely be ascribed to the relative contributions of the groups $\mathrm{C}(15.0 \%), \mathrm{P}$ (15.0\%), D (9.4\%), MP (9.1\%), M (8.3\%), X1 (7.5\%), and S1 (6.8\%) (Supplementary Table S2).

We detected significant differences in MBFG composition between within the P. magnifica matrix and in the waterbodies (Table 3). The NMDS results showed that four of seven MBFGs contributed significantly $(\mathrm{p}<0.01)$ to the ordination axis (Fig. 3B). Four groups, I, III, VI, and VII, explained the separation of sampling sites in the waterbodies, but not within the colonies. The ANOSIM results supported the positions of the two environmental regimes determined by ordination. There was more dis- similarity between the two regimes than within them $(\mathrm{R}=$ $0.133, p=0.023$ ). The PERMANOVA results also supported significant differences in community composition between environmental regimes (pseudo- $\mathrm{F}_{1,25}=4.476, \mathrm{p}=$ 0.008 ), but were dependent on the sampling site considered (pseudo- $\mathrm{F}_{4,25}=2.265, \mathrm{p}=0.022$ ). Results of SIMPER analysis showed that groups III (19.1\%), VII (17.8\%), and I (16.6\%) were primarily responsible for discriminating the two habitats (Supplementary Table S3).

Spatial heterogeneity was detected among the waterbodies but not among the colonies in terms of both FG composition and MBFG composition. The ANOSIM results supported the group positions determined by ordination. Differences in FG composition among sites within the environmental regimes were not detected in the colonies $(\mathrm{R}=0.113, \mathrm{p}=0.218)$ but were detected in the

Table 2. Relative abundance of each functional group (FG) and morphologically based functional group (MBFG) on a natural-log scale within Pectinatella magnifica and in the waterbodies

\begin{tabular}{|c|c|c|c|c|c|}
\hline FG & $\begin{array}{c}\text { Within } \\
\text { P. magnifica }(\%)\end{array}$ & $\begin{array}{c}\text { In waterbodies } \\
(\%)\end{array}$ & MBFG & $\begin{array}{c}\text { Within } \\
\text { P. magnifica (\%) }\end{array}$ & $\begin{array}{c}\text { In waterbodies } \\
(\%)\end{array}$ \\
\hline A & - & 1.83 & I & 16.81 & 13.44 \\
\hline B & 1.71 & 1.44 & II & 2.41 & 7.36 \\
\hline $\mathrm{C}$ & - & 12.25 & III & 11.99 & 9.53 \\
\hline $\mathrm{D}$ & - & 8.05 & IV & 31.84 & 22.84 \\
\hline $\mathrm{G}$ & 5.92 & 0.95 & $\mathrm{~V}$ & 1.99 & 5.49 \\
\hline $\mathrm{H} 1$ & 1.86 & 4.37 & VI & 18.35 & 25.11 \\
\hline $\mathrm{J}$ & 16.76 & 12.56 & VII & 16.61 & 16.23 \\
\hline M & 6.40 & 7.10 & - & - & - \\
\hline MP & 12.93 & 8.26 & - & - & - \\
\hline $\mathrm{N}$ & 1.79 & - & - & - & - \\
\hline $\mathrm{P}$ & 3.87 & 13.85 & - & - & - \\
\hline $\mathrm{S} 1$ & 27.19 & 11.10 & - & - & - \\
\hline $\mathrm{W}_{\mathrm{S}}$ & 1.99 & 4.34 & - & - & - \\
\hline $\mathrm{X} 1$ & 11.72 & 10.44 & - & - & - \\
\hline Others & 7.86 & 3.46 & - & - & - \\
\hline
\end{tabular}

Groups that contributed little to total biomass are presented as "Others."

- , not observed.

Table 3. Non-metric multidimensional scaling and analysis of similarity (ANOSIM) results comparing the composition of functional groups and morphologically based functional groups among environmental regimes and sites

\begin{tabular}{|c|c|c|c|}
\hline Trials & Stress $(\%)$ & Non-metric $\mathbf{r}^{2}$ & ANOSIM R (p-value) \\
\hline \multicolumn{4}{|l|}{ Functional group composition } \\
\hline Environmental regimes & 17.5 & 0.969 & $0.598(0.001)$ \\
\hline \multicolumn{4}{|l|}{ Sites } \\
\hline Within Pectinatella magnifica & 8.8 & 0.992 & $0.113(0.218)$ \\
\hline In the waterbodies & 9.6 & 0.991 & $0.438(0.009)$ \\
\hline \multicolumn{4}{|c|}{ Morphologically based on functional group composition } \\
\hline Environmental regimes & 15.5 & 0.976 & $0.133(0.023)$ \\
\hline \multicolumn{4}{|l|}{ Sites } \\
\hline Within P. magnifica & 11.9 & 0.991 & $0.191(0.166)$ \\
\hline In the waterbodies & 10.1 & 0.990 & $0.300(0.048)$ \\
\hline
\end{tabular}



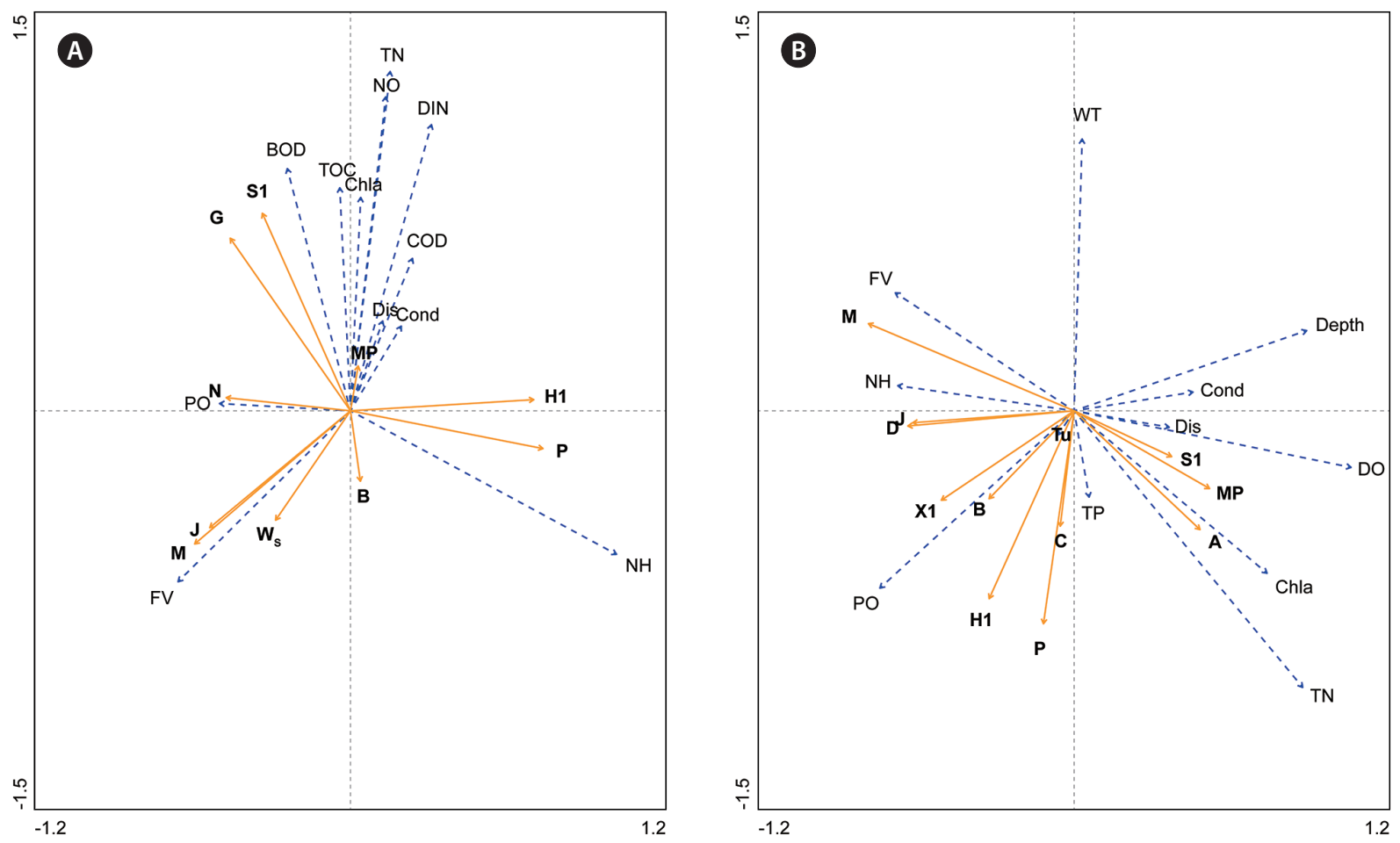

Fig. 4. Biplot diagram for the redundancy analysis of the relationship between 12 environmental variables (dash lines) and phytoplankton functional groups (solid lines) within the Pectinatella magnifica colonies (A) and in the waterbodies (B). The environmental variables are as follows: BOD, biological oxygen demand; Chla, chlorophyll a concentration; COD, chemical oxygen demand; Cond, conductivity; Depth, river depth; DIN dissolved inorganic nitrogen; Dis, discharge; DO, dissolved oxygen; NH, ammonium; NO, nitrate; PO, orthophosphate; TN, total nitrogen; TP, total phosphorus; TOC, total organic carbon; Tu, turbidity; WT, water temperature; FV, flow velocity.

waterbodies $(\mathrm{R}=0.438, \mathrm{p}=0.009)$. Groups $\mathrm{M}(\mathrm{p}=0.007)$ and X1 ( $p=0.003$ ) were the key features of the compositional differences between sites. Similar to the MBFG ordination results, the algal communities did not show differences between sites within the bryozoan matrices ( $\mathrm{R}=0.191, \mathrm{p}=0.166)$ but did show differences between sites in the surrounding water $(R=0.300, p=0.048)$.

\section{Relationships with water quality parameters}

Spatial variations in FG composition in the waterbodies were dependent on the values of $\mathrm{TN}(\mathrm{F}=2.69$, $\mathrm{p}$ $=0.005)$ and PO $(\mathrm{F}=1.90, \mathrm{p}=0.040)$, but there were no significant variables within the colonies $(\mathrm{NH}: \mathrm{F}=1.45$, $\mathrm{p}=0.125$; BOD: $\mathrm{F}=1.38, \mathrm{p}=0.145$ ) (Fig. 4). The relative eigenvalues of axes 1 and 2 were $0.25,0.20$ within the $P$. magnifica matrix and 0.27 and 0.22 in the waterbodies, respectively. The sum of the canonical axes accounted for $44 \%$ and $50 \%$ of total variance in functional groups, respectively. In the waterbodies, groups B and X1 had a positive correlation with the PO value, and groups S1 and MP had a negative relationship with the flow velocity.

\section{DISCUSSION}

Associated algal communities with $P$. magnifica showed a clearly different environmental regime from that of the surrounding water body and had an imbalanced high density and dominance of Planktothrix kawamurae and Pseudanabaena catenata. This suggests that this regime was not beneficial to the level of the community but was sustainable for a few dominant species to proliferate (Xu et al. 1999, 2001). The properties of the dominant functional group within the colonies, S1, were typical of those of warm mixed layers; they consisted of only shade-adapted cyanoprokaryotes that can adapt easily to light deficiency, but are sensitive to flushing (Reynolds et al. 2002, Padisák et al. 2009). Two dominant cyanobacteria in this study had the ability to move and catch the optimal light and chemical conditions, usually forming benthic mats or being tychoplanktonic in the eutrophic system (Stal 2012). The most common species, Pseudanabaena catenata, could endure the limiting constraints by zooids on the surface of $P$. magnifica by using their preferential adaptation strategy to regulate the 
phycoerythrin / phycocyanin ratio (Mishra et al. 2012, Yu et al. 2015). Although much of the ecology of Planktothrix kawamurae remains unclear, their trichomes are extremely large; thus, this species can represent a significant portion of associated algal communities in terms of biomass (Ichise et al. 1999).

Phytoplankton assemblages used for describing community structure and functions reflect the conditions of the water body. The two studied rivers are enriched systems; therefore, their phytoplankton FGs were dominated by C, D, M, and P, all of which were characterized by an enriched habitat template. Groups $\mathrm{C}$ and P, comprising Aulacoseira and sharing their tolerances and constraints, were the most common phytoplankton FGs, because of their tolerance to silicate depletion (Reynolds et al. 2002, Padisák et al. 2009). In addition, MBFGs I, III, IV, and VII defined the site-specific characteristics of algal communities (Kruk et al. 2010). The main drivers for each group were different: both TN and TP for group I, TP for group III, TN for group IV, and reactive soluble silicate for group VII (Kruk and Segura 2012).

However, FG composition within P. magnifica regimes was not explained by any water quality parameter, which indicates that these regimes are distinctive habitat. For example, groups $\mathrm{M}$ and $\mathrm{S1}$, which are sensitive to flushing, did not exhibit negative relationships with flow velocity and were even positively associated, thanks to the gelatinous matrices of the bryozoans. Furthermore, the spatial homogeneity of the associated algae supports the hypothesis that the regime would be function as a habitat for cyanobacteria tolerant to low light conditions. Intensive interaction between the sediment and water, and specific abilities, such as buoyancy regulation, to exploit habitat resources can support the success of algal communities (Nixdorf et al. 2003, Rojo and Álvarez-Cobelas 2003).

From our study, habitat-forming bryozoans appear to increase the spatial complexity and alter the conditions of local environments, often facilitating the assemblage of the most successful algae. The relationship between species adaptive properties and community diversity stabilizes the functional properties of aggregated communities (May and Mac Arthur 1972, Gadgil and Gadgil 1975). Freshwater bryozoans provide habitats for associated aufwuchs, as well as algal communities (Bushnell and Rao 1979). Therefore, their body cavities could be abundance hotspots for algae, benthic detritivores, and black fly larvae, and could even host myxozoan parasites (Hakenkamp et al. 2001, Canning et al. 2002).

The present study also revealed that a trait-based ap- proach could elucidate the ecological status of algal communities associated with freshwater bryozoans and river phytoplankton, even though the scale of our study was relatively narrow. In previous studies on algae associated with those bryozoans, Joo et al. (1992) and Šetlíková et al. (2013) asserted that the higher nutrient contents in enclosed microhabitats provided species with the opportunity to flourish and colonize. However, according to the trait-based classified template, the habitat appears to be susceptible to being colonized by algal communities due to the species' low-light tolerance, rather than its nutrient rich matrix, which is supported by similar dominant functional groups within our observations (Reynolds et al. 2002). Thus, these trait-based approaches to algal communities allow the representation of microhabitats where biological processes are not established and are helpful in evaluating the function of the habitat.

\section{ACKNOWLEDGEMENTS}

We feel it deeply appropriate and courteous to thank the Associate Editor (Dr. K. Y. Kim) and anonymous reviewer with thorough revisions. Also, we appreciated Dr. S. Hong for advice on improving our manuscript. This work was supported by grants from the Basic Research Program (NRF-2016R1D1A1B01009492) supported by the National Research Foundation (NRF) of Korea.

\section{SUPPLEMENTARY MATERIAL}

Supplementary Table S1. Relative abundance, functional group (FG), and morphologically based functional group (MBFG) of algal species inside and outside of Pectinatella magnifica (https://www.e-algae.org).

Supplementary Table S2. Results of similarity percentage analyses (SIMPER) illustrating functional groups that differentiate between the inside and outside of Pectinatella magnifica (https://www.e-algae.org).

Supplementary Table S3. Results of similarity percentage analyses (SIMPER) illustrating morphologically based functional groups that differentiate between the inside and outside of Pectinatella magnifica (https:// www.e-algae.org).

\section{REFERENCES}

Akiyama, M. 1977. Illustrations of the Japanese fresh-water 
algae. Uchidarokakuho Publishing Company, Tokyo, $933 \mathrm{pp}$.

Bertness, M. D., Leonard, G. H., Levine, J. M., Schmidt, P. R. \& Ingraham, A. O. 1999. Testing the relative contribution of positive and negative interactions in rocky intertidal communities. Ecology 80:2711-2726.

Bushnell, J. H. \& Rao, K. S. 1979. Freshwater Bryozoa: microarchitecture of statoblasts and some aufwuchs animal associations. In Larwood, G. P. \& Abbott, M. B. (Eds.) Advances in Bryozoology. Academic Press, London, 639 pp.

Canning, E. U., Tops, S., Curry, A., Wood, T. S. \& Okamura, B. 2002. Ecology, development and pathogenicity of Buddenbrockia plumatellae Schröder, 1910 (Myxozoa, Malacosporea) (Csyn. Tetracapsula bryozoides) and establishment of Tetracapsuloides $\mathrm{n}$. gen. for Tetracapsula bryosalmonae. J. Eukaryot. Microbiol. 49:280-295.

Gadgil, S. \& Gadgil, M. 1975. Can a single resource support many consumer species? J. Genet. 62:33-47.

Hakenkamp, C. C., Ribblett, S. G., Palmer, M. A., Swan, C. M., Reid, J. W. \& Goodison, M. R. 2001. The impact of an introduced bivalve (Corbicula fluminea) on the benthos of a sandy stream. Freshw. Biol. 46:491-501.

Hillebrand, H., Dürselen, C. -D., Kirschtel, D., Pollingher, U. \& Zohary, T. 1999. Biovolume calculation for pelagic and benthic microalgae. J. Phycol. 35:403-424.

Ichise, S., Wakabayashi, T., Mizushima, K., Fujiwara, N. \& Nomura, K. 1999. Aspect of the occurrence of water-bloom in Lake Biwa: growth of Oscillatoria kawamurae in 1998. Rep. Shiga Pref. Inst. Publ. Health Environ. Sci. 34:84-90.

Jo, H., Joo, G. -J., Byeon, M., Hong, D. -G., Gim, J. -S., Kim, J. -Y. \& Choi, J. -Y. 2014. Distribution pattern of Pectinatella magnifica (Leidy, 1851), an invasive species, in the Geum River and the Nakdong River, South Korea. J. Ecol. Environ. 37:217-223.

Joo, G. -J., Ward, A. K. \& Ward, G. M. 1992. Ecology of Pectinatella magnifica (Bryozoa) in an Alabama oxbow lake: colony growth and association with algae. J. N. Am. Benthol. Soc. 11:324-333.

Kruk, C., Huszar, V. L. M., Peeters, E. T. H. M., Bonilla, S., Costa, L., Lürling, M., Reynolds, C. S. \& Scheffer, M. 2010. A morphological classification capturing functional variation in phytoplankton. Freshw. Biol. 55:614-627.

Kruk, C., Peeters, E. T. H. M., Van Nes, E. H., Huszar, V. L. M., Costa, L. S. \& Scheffer, M. 2011. Phytoplankton community composition can be predicted best in terms of morphological groups. Limnol. Oceanogr. 56:110-118.

Kruk, C. \& Segura, A. M. 2012. The habitat template of phytoplankton morphology-based functional groups. Hydrobiologia 698:191-202.

Lavorel, S., McIntyre, S., Landsberg, J. \& Forbes, T. D. A. 1997.
Plant functional classifications: from general groups to specific groups based on response to disturbance. Trends Ecol. Evol. 12:474-478.

LeGresley, M. \& McDermott, G. 2010. Counting chamber methods for quantitative phytoplankton analysis-haemocytometer, Palmer-Maloney cell and Sedgewick-Rafter cell. In Karlson, B., Cusack, K. \& Bresnan, E. (Eds.) Microscopic and Molecular Methods for Quantitative Phytoplankton Analysis. IOC Manuals and Guides. UNESCO, Paris, pp. 25-30.

Lilley, S. A. \& Schiel, D. R. 2006. Community effects following the deletion of a habitat-forming alga from rocky marine shores. Oecologia 148:672-681.

Litchman, E., de Tezanos Pinto, P., Klausmeier, C. A., Thomas, M. K. \& Yoshiyama, K. 2010. Linking traits to species diversity and community structure in phytoplankton. Hydrobiologia 653:15-28.

Magurran, A. E. 1988. Ecological diversity and its measurement. Princeton University Press, Princeton, NJ, 179 pp.

May, R. M. \& Mac Arthur, R. H. 1972. Niche overlap as a function of environmental variability. Proc. Natl. Acad. Sci. U. S. A. 69:1109-1113.

McGill, B. J., Enquist, B. J., Weiher, E. \& Westoby, M. 2006. Rebuilding community ecology from functional traits. Trends Ecol. Evol. 21:178-185.

Mishra, S. K., Shrivastav, A., Maurya, R. R., Patidar, S. K., Haldar, S. \& Mishra, S. 2012. Effect of light quality on the C-phycoerythrin production in marine cyanobacteria Pseudanabaena sp. isolated from Gujarat coast, India. Protein Expr. Purif. 81:5-10.

Nixdorf, B., Mischke, U. \& Rücker, J. 2003. Phytoplankton assemblages and steady state in deep and shallow eutrophic lakes: an approach to differentiate the habitat properties of Oscillatoriales. Hydrobiologia 502:111121.

Padisák, J., Crossetti, L. O. \& Naselli-Flores, L. 2009. Use and misuse in the application of the phytoplankton functional classification: a critical review with updates. Hydrobiologia 621:1-19.

Reynolds, C. S., Huszar, V., Kruk, C., Naselli-Flores, L. \& Melo, S. 2002. Towards a functional classification of the freshwater phytoplankton. J. Plankton Res. 24:417-428.

Rojo, C. \& Álvarez-Cobelas, M. 2003. Are there steady-state phytoplankton assemblages in the field? Hydrobiologia 502:3-12.

Ruhí, A., Herrmann, J., Gascón, S., Sala, J., Geijer, J. \& Boix, D. 2011. Change in biological traits and community structure of macroinvertebrates through primary succession in a man-made Swedish wetland. Freshw. Sci. 31:22-37.

Salmaso, N., Naselli-Flores, L. \& Padisák, J. 2015. Functional 
classifications and their application in phytoplankton ecology. Freshw. Biol. 60:603-619.

Seo, J. E. 1998. Taxonomy of the freshwater bryozoans from Korea. Korean J. Syst. Zool. 14:371-381.

Šetlíková, I., Skácelová, O., Šinko, J., Rajchard, J. \& Balounová, Z. 2013. Ecology of Pectinatella magnifica and associated algae and cyanobacteria. Biologia 68:1136-1141.

Stal, L. J. 2012. Cyanobacterial mats and stromatolites. In Whitton, B. A. (Ed.) Ecology of Cyanobacteria II: Their Diversity in Space and Time. Springer, Berlin, pp. 65-125.

Stimson, J. 1985. The effect of shading by the table coral Acropora hyacinthus on understory corals. Ecology 66:40-53.

Vollenweider, R. A. 1976. Advances in defining critical loading levels for phosphorus in lake eutrophication. Mem. Ist. Ital. Idrobiol. dott. Marco de Marchi 33:53-83.

Wood, A. C. L., Probert, P. K., Rowden, A. A. \& Smith, A. M. 2012. Complex habitat generated by marine bryozoans: a review of its distribution, structure, diversity, threats and conservation. Aquat. Conserv. Mar. Freshw. Ecosyst. 22:547-563.

Xu, F. -L., Jørgensen, S. E. \& Tao, S. 1999. Ecological indicators for assessing freshwater ecosystem health. Ecol. Modell. 116:77-106.

Xu, F. -L., Tao, S., Dawson, R. W., Li, P. -G. \& Cao, J. 2001. Lake ecosystem health assessment: indicators and methods. Water Res. 35:3157-3167.

Yamagishi, T. \& Akiyama, M. 1984. Photomicrographs of the fresh-water algae. Uchida Rokakuho, Tokyo, $100 \mathrm{pp}$.

Yu, G., Zhu, M., Chen, Y., Pan, Q., Chai, W. \& Li, R. 2015. Polyphasic characterization of four species of Pseudanabaena (Oscillatoriales, Cyanobacteria) from China and insights into polyphyletic divergence within the Pseudanabaena genus. Phytotaxa 192:1-12.

Zar, J. H. 1999. Biostatistical analysis. 4th ed. Pearson Education, New Delhi, 663 pp. 